\title{
PENGARUH PENCITRAAN, PROMOSI DAN KUALITAS PELAYANAN TERHADAP MINAT MAHASISWA UNTUK MEMILIH PERGURUAN TINGGI SWASTA DI PROVINSI SUMATERA UTARA
}

\author{
Oleh \\ Joana L. Saragih
}

\begin{abstract}
Abstrak
Tujuan dari penelitian ini untuk mengetahui dan menganalisis pengaruh pencitraan, promosi dan kualitas pelayanan terhadap minat mahasiswa untuk memilih Perguruan Tinggi Swasta di Provinsi Sumatera Utara. Jenis penelitian ini adalah penelitian deskriptif yang didasarkan atas survey terhadap objek penelitian untuk menggambarkan suatu fenomena berkaitan dengan populasi penelitian atau estimasi proporsi populasi yang mempunyai karakteristik tertentu .Populasi dalam penelitian ini adalah seluruh siswa kelas 3(tiga) SMU yang ada di Provinsi Sumatera Utara. Pemilihan sampel data dilakukan secara purposive sampling, yaitu seleksi data yang didasarkan pada kriteria tertentu atau judgement sampling. Sampel penelitian dipilih 10(sepuluh) SMU yang dianggap repsentatif dan yang diteliti hanya siswa kelas 3(tiga) dengan perincian dipilih 30 siswa dari masing - masing SMU yang terpilih sebagai obyek penelitian, maka jumlah sampel sebanyak 300 responden. Metode pengumpulan data yang digunakan dalam penelitian ini adalah : Wawancara (Interview), Koesioner (Questionaire) dan Studi Dokumentasi. Metode analisis dengan regresi berganda dengan melakukan uji asumsi klasik yaitu : uji normalitas, uji multikolonieritas dan uji heteroskedastisitas kemudian di uji dengan uji $\mathrm{F}$ dan uji t untuk melihat pengaruh Pencitraan, Promosi dan Kualitas Pelayanan Terhadap Minat Mahasiswa untuk memilih Perguruan Tinggi Swasta di Provinsi Sumatera Utara.
\end{abstract}

Kata Kunci: Pencitraan, Promosi, Kualitas Pelayanan, Minat Mahasiswa

\section{PENDAHULUAN}

Pendidikan sangat penting dalam aspek kehidupan saat ini terlebih untuk mengantisipasi persaingan dunia kerja di masa yang akan datang. Pendidikan yang berkualitas menjadikan seseorang memiliki modal investasi masa depan. Jika dilihat dari berbagai sisi, manfaat yang diperoleh apabila seseorang memiliki suatu basic pendidikan yang berkualitas dengan modal pendidikan yang baik, pengaruhnya untuk jangka panjang. Jangka panjang yang dapat dirasakan adalah pada karir seseorang apabila sudah terjun di dunia kerja akan memperhatikan adanya basic pendidikan yang berkualitas. Permasalahannya bagaimana mendapatkan pendidikan yang berkualitas, berkompeten, dan dapat dijadikan investasi masa depan yang di dukung oleh suatu institusi yang 
mampu memberikan pelayanan jasa pendidikan yang berkualitas. Pada saat ini banyak universitas - universitas di Indonesia yang memberikan banyak pilihan program studi yang berstandar nasional.

Indrajit (2006), menjelaskan ada 5 dimensi makna pada perguruan tinggi atau institusi di bidang pendidikan yaitu : dimensi keilmuan (ilmu dan teknologi), dimensi pendidikan (pendidikan tinggi), dimensi sosial (kehidupan masyarakat), dimensi korporasi (satuan pendidikan dan penyelenggaraan) dan dimensi etis.

Paul J dan Olson, Jerry C. (2000) mendefinisikan minat sebagai hasil suatu pemikiran seseorang dimana setelah melihat tentang spesifikasi suatu produk atau jasa, dan memiliki keinginan untuk mencoba untuk dapat memenuhi suatu kebutuhan, di dalam hal ini konsumen akan cenderung benar-benar memilih, menimbang dan menilai apakah suatu produk atau jasa yang dianggap belum diketahui konsumen, sehingga apabila produk atau jasa tersebut benar-benar mampu memenuhi ekspektasi pelanggan, maka konsumen timbul suatu minat untuk mencoba produk atau jasa tersebut.

Menurut Alma 2002 dalam Chrisdiawan Satriyo Nugroho, 2010, memberikan pandangan bahwa pencitraan adalah kesan yang di peroleh sesuai dengan pengetahuan dan pengalaman seseorang tentang sesuatu obyek. Citra dianggap memiliki kemampuan untuk mempengaruhi persepsi pelanggan terhadap barang dan jasa yang ditawarkan. Sikap dan tindakan seseorang terhadap suatu obyek sangat ditentukan oleh pencitraan obyek tersebut, pada industri jasa dan bussiness to bussiness, merek atau jasa sering dikaitkan dengan pencitraan suatu perusahaan. Maka di simpulkan bahwa pencitraan merupakan keseluruhan persepsi yang terbentuk dari obyek berdasarkan informasi dan pengalaman masa lalu konsumen.

Selain pencitraan, promosi juga merupakan hal yang sangat penting untuk mempengaruhi, membujuk dan melakukan pembelian terhadap suatu produk. Promosi adalah kegiatan mengkomunikasikan informasi dari penjual kepada pembeli atau pihak lain dalam saluran untuk mempengaruhi sikap dan perilaku (Tjiptono. 1999). Tugas perusahaan dalam promosi adalah memberitahu pelanggan target tentang ketersediaan produk yang tepat pada tempat yang tepat dan harga yang tepat pula. Strategi promosi dengan menggabungkan periklanan, penjualan perorangan, promosi penjualan dan publisitas menjadi program terpadu untuk berkomunikasi dengan para pembeli dan orang lain yang mempengaruhi minat . Promosi digunakan untuk menginformasikan kepada orang mengenai produk atau jasa dan meyakinkan konsumen dalam 
pasar sasaran untuk membeli atau menggunakan produk atau jasa, fungsi promosi dalam bauran pemasaran adalah untuk mencapai berbagai tujuan komunikasi dengan setiap konsumen, dengan demikian diharapkan pengenalan produk atau jasa pada masyarakat berlangsung baik. Selain pencitraan dan promosi, kualitas pelayanan juga merupakan hal yang sangat penting untuk menarik minat calon pembeli terhadap suatu produk. Kualitas pelayanan merupakan tingkat kesesuaian dengan persyaratan, dalam hal ini persyaratan pelanggan.

Adapun masalah penelitian adalah :

a. Bagaimana pengaruh pencitraan dan promosi terhadap minat mahasiswa memilih Perguruan Tinggi Swasta yang ada di Provinsi Sumatera Utara.

b. Bagaimana pengaruh pencitraan dan kualitas pelayanan terhadap minat mahasiswa memilih Perguruan Tinggi Swasta yang ada di Provinsi Sumatera Utara.

c. Bagaimana pengaruh promosi dan kualitas pelayanan terhadap minat mahasiswa memilih Perguruan Tinggi Swasta yang ada di Provinsi Sumatera Utara.

d. Bagaimana pengaruh pencitraan, promosi dan kualitas pelayanan terhadap minat mahasiswa memilih Perguruan Tinggi Swasta yang ada di Provinsi Sumatera Utara.

\section{TINJAUAN PUSTAKA}

\section{Pencitraan}

Pencitraan merupakan asosiasi yang muncul dalam benak konsumen ketika mengingat suatu merek atau jasa tertentu. Asosiasi secara sederhana dapat muncul dalam bentuk pemikiran atau citra tertentu yang dikaitkan dengan suatu merek. Sutisna (2001) memaparkan ada beberapa manfaat suatu institusi atau perusahaan menampilkan citra yang positif, yaitu : pertama, muncul suatu kepercayaan. Yang kedua kebijakan family branding dan leverage branding dapat dilakukan jika citra perusahaan telah positif. Kotler (2000), mendefinisikan citra "Seperangkat keyakinan, ide dan kesan yang dimiliki seseorang terhadap suatu objek", selanjutnya beliau mengatakan "Sikap dan tindakan seseorang terhadap suatu objek sangat dikondisikan oleh citra objek tersebut", ini memberi arti bahwa kepercayaan, ide serta impresi seseorang sangat besar pengaruhnya terhadap sikap dan perilaku serta respon yang mungkin akan dilakukannya. 
Perusahaan akan dilihat melalui citranya, baik citra itu negatif atau positif. Citra yang positif akan memberikan arti yang baik terhadap produk perusahaan tersebut dan seterusnya dapat meningkatkan jumlah penjualan produk atau jasa, sebaliknya penjualan produk suatu perusahaan akan jatuh atau mengalami kerugian jika citranya dipandang negatif oleh masyarakat. Menurut Tjiptono (1999), pencitraan adalah penilaian yang diberikan masyarakat atau konsumen kepada perusahaan, sehingga timbul adanya suatu persepsi tentang kegiatan yang dilakukan perusahaan selama ini. Citra adalah penghargaan yang didapatkan oleh perusahaan karena adanya keunggulan yang ada pada perusahaan tersebut. Citra perusahaan dapat di lihat dari kompetensi dan keunggulan perusahaan. Kompetensi yang dimiliki suatu perusahaan dapat di lihat dari :

1. Staf dan karyawan yang dimiliki perusahaan tersebut.

2. Perusahaan memiliki suatu kredibilitas.

3. Memiliki manajemen yang berpengalaman.

4. Tingkat reputasi yang lebih baik daripada pesaing.

5. Dikenal oleh masyarakat luas.

\section{Promosi}

Promosi merupakan salah satu variabel dalam marketing mix yang sangat penting dilakukan oleh perusahaan dalam memasarkan produknya. Menurut Swastha (2000) promosi dapat diartikan sebagai arus informasi atau persuasi satu arah yang dibuat untuk mengarahkan seseorang atau organisasi kepada tindakan menciptakan pertukaran dalam pemasaran. Sedangkan Tjiptono (1999), mengatakan promosi adalah aktivitas pemasaran yang berusaha menyebarkan informasi, mempengaruhi atau membujuk dan mengingatkan pasar sasaran atas perusahaan dan produknya agar bersedia menerima, membeli dengan loyal pada produk yang ditawarkan perusahaan yang bersangkutan. Menurut Kotler dan Gary (2004), Promotional mix adalah kombinasi strategi yang paling baik dari variabel-variabel periklanan, personal selling dan alat promosi yang lain, yang semuanya direncanakan untuk mencapai tujuan program penjualan. Variabel-variabel promotional mix dibagi menjadi :

1. Periklanan. Periklanan berfungsi sebagai ujung tombak perusahaan dalam menghadapi persaingan. Periklanan dirancang untuk memberitahu atau meyakinkan pembeli tentang produk, jasa, keyakinan dan tindakan. Periklanan digunakan ketika pihak perusahaan ingin berkomunikasi dengan sejumlah orang yang tidak dapat dijangkau baik secara ekonomis maupun secara efektif melalui pendekatan personal, 
komunikasi yang dilakukan bersifat massal, menggunakan media seperti radio, TV, majalah, surat kabar dan sebagainya. Periklanan dapat dibedakan menjadi dua golongan yaitu :

a. Pull demand advertising, merupakan periklanan yang ditujukan kepada konsumen akhir agar permintaan produk yang bersangkutan meningkat.

b. Push demand advertising, merupakan periklanan yang ditujukan kepada para penyalur, maksudnya adalah agar para penyalur bersedia meningkatkan permintaan produksi dengan menjual sebanyak mungkin kepada penjual maupun pengecer.

Upaya melakukan periklanan menyangkut tujuan mendorong permintaan terhadap suatu merek atau jasa tertentu, berdasarkan hal ini iklan dapat digolongkan menurut jenisnya menjadi:

a. Iklan merek (brand advertising), merupakan iklan yang membantu meningkatkan konsumsi diantara pelanggan sekarang, menarik pelanggan baru dan mempertahankan pelanggan yang telah diraih.

b. Iklan kerjasama ( coorporative advertising), merupakan upaya gabungan yang dilakukan perusahaan manufaktur dan pengecer untuk menjual produk.

c. Iklan korporasi (corporate institutional advertising), bertujuan untuk memberi manfaat pada perusahaan dengan membangun sikap yang mengesankan terhadap perusahaan secara menyeluruh.

2. Personal Selling. Penjualan personal merupakan cara promosi paling penting yang digunakan untuk menambah penjualan yang menguntungkan dengan menawarkan pemenuhan kebutuhan dalam jangka panjang. Personal selling terjadi interaksi langsung saling bertemu antara penjual dengan pembeli. Komunikasi yang dilakukan kedua belah pihak bersifat individual dengan dua arah sehingga penjual dapat langsung memperoleh tanggapan sebagai umpan balik tentang keinginan dan kesukaan pembeli. Penyampaian berita atau percakapan yang mereka lakukan sangat fleksibel karena dapat menyesuaikan dengan situasi yang ada.

3. Publisitas. Publisitas salah satu tipe komunikasi yang merupakan bagian dari fungsi yang lebih luas, yang disebut dengan hubungan masyarakat. Kegiatan humas ini sangat membantu perusahaan dalam mencari kesuksesan, karena merupakan komunikasi dengan masyarakat luas yang dapat mempengaruhi kesan terhadap sebuah produk atau jasa yang ditawarkan. Keuntungan dari publisitas yaitu :

a. Menjangkau orang-orang yang tidak mau membaca sebuah iklan. 
b. Dapat ditempatkan pada halaman depan dari sebuah surat kabar atau berada posisi lain yang mencolok.

c. Lebih dapat di percaya.

d. Publisitas jauh lebih murah karena dilakukan secara bebas tanpa memungut biaya.

Kelemahan dari publisitas antara lain bahwa publisitas tidak dapat menggantikan peranan dari alat promosi yang lain, publisitas hanya mendukung metode promosi yang lain dan harus dipertimbangkan sebagai suatu elemen dalam program komunikasi pemasaran secara keseluruhan.

4. Promosi Penjualan. Promosi penjualan adalah suatu kegiatan yang dilakukan oleh perusahaan dengan tujuan memberikan informasi kepada konsumen serta membujuk konsumen untuk menggunakan produk atau jasa perusahaan tersebut. Kegiatan yang mencakup peragaan, pertunjukkan, pameran, demonstrasi dan sebagainya tersebut dapat diwujudkan dalam bentuk :

a. Promosi dilakukan dengan memanfaatkan suatu media. Dalam hal ini, kegiatan promosi yang bersifat menyampaikan suatu informasi dapat disalurkan ke suatu media, baik itu media cetak atau media massa dan media elektronik dengan tujuan menyampaikan pesan ke khalayak umum.

b. Promosi dengan memberikan suatu demonstrasi di tempat umum. Demonstrasi ini, mengacu pada visualisasi secara langsung kepada masyarakat, dengan cara berpromosi memberikan informasi secara langsung di tempat umum dengan menggunkan media seperti poster,spanduk atau media yang lain.

c. Promosi dengan menyelenggarakn suatu event atau pameran tertentu. Promosi ini mengacu untuk memberikan dukungan terhadap suatu event atau pameran tertentu dengan menyelipkan informasi tentang promosi yang diberikan kepada masyarakat yang mengikuti event atau pameran tersebut.

d. Memberikan suatu inovasi dalam berpromosi. Promosi yang terkesan biasa saja, membuat masyarakat menjadi kurang tertarik terhadap produk atau jasa yang ditawarkan, sehingga untuk mengatasi hal tersebut perusahaan harus menciptakan suatu terobosan atau inovasi tertentu, seperti memberikan diskon atau potongan harga, memberikan souvenir atau hadiah tertentu dalam promosi. 


\section{Kualitas Pelayanan}

Tingkat keberhasilan dan kualitas perusahaan adalah kemampuan perusahaan dalam memberikan pelayanan pelanggan. Zeithaml (1988) menjelaskan bahwa, kualitas pelayanan merupakan evaluasi konsumen tentang kesempurnaan kinerja pelayanan. Kualitas pelayanan merupakan tingkat keunggulan untuk memenuhi harapan pelanggan yang di bentuk oleh perbandingan antara ideal dan persepsi dari kinerja kualitas. Salah satu pendekatan kualitas pelayanan yang banyak dijadikan acuan dalam riset pemasaran adalah model "SERVQUAL" (service quality) yang dikembangkan oleh Zeithaml, Parasuraman dan Berry. Model ini dibangun atas persepsi pelanggan atas pelayanan nyata yang diterima (perceived service). Jika kenyataan lebih dari yang diharapkan, maka pelayanan dapat dikatakan bermutu, apabila kenyataan sama dengan harapan maka pelayanan disebut memuaskan, dengan demikian kualitas pelayanan dapat didefinisikan sebagai seberapa jauh perbedaan antar kenyataan dengan harapan pelanggan atas pelayanan yang diterima oleh pelanggan (Lamb, Charles W; Hair, Joseph F., McDaniel, Carl. 2001. Dengan mengoptimalkan tingkat kualitas pelayanan, maka suatu perusahaan dapat memperoleh berbagai keuntungan, diantaranya adalah :

a. Mempertahankan konsumen

b. Menghindari persaingan harga

c. Mempertahankan karyawan yang berkualitas.

Parasuraman, Zeithmal dan Berry, dalam penelitian tentang kualitas jasa berhasil mengidentifikasikan 5 dimensi kualitas jasa berdasarkan persepsi konsumen. Tiga diantaranya yakni Ketanggapan, Jaminan dan Empati merupakan dimensi-dimensi yang menggambarkan upaya-upaya karyawan, dari sudut pandang pemasaran maka faktor manusialah yang mampu membedakan antara jasa yang satu dengan jasa yang lain, kemudian dalam studinya membagi instrumen Servqual yang dikembangkan oleh Parasuraman menjadi elemen manusia dan elemen tangibel. Elemen manusia terdiri dari reliabilitas, daya tanggap, jaminan dan empati. Dari pembahasan tentang telaah pustaka tentang masalah kualitas pelayanan, dapat diambil suatu kesimpulan bahwa kualitas pelayanan didefinisikan sebagai kemampuan perusahaan dalam memenuhi harapan konsumen, dengan tujuan agar konsumen mau menggunakan dan membayar pelayanan yang diberikan perusahaan. Ada 5 dimensi pokok kualitas pelayanan menurut Zeithaml, Parasuraman dan Barry yaitu:

a. Tangibles. Penampilan fisik pelayanan, karyawan, komunikasi serta tingkat teknologi yang digunakan perusahaan dapat berpengaruh pada 
pandangan pelanggan akan kesiapan perusahaan dalam memberikan pelayanan.

b. Reliability.Kemampuan perusahaan untuk melaksanakan dan memenuhi pelayanan yang telah dijanjikan secara akurat, misal ketepatan waktu, kekonsistenan dan kecepatan pelayanan, selain itu penanganan keluhan pelanggan juga berpengaruh terhadap kualitas pelayanan.

c. Responsiveness. Kemampuan, kemauan serta kepedulian perusahaan untuk membantu pelanggan serta memberikan pelayanan terbaik.

d. .Assurance ( Jaminan). Pengetahuan, kemampuan serta sikap karyawan (tanggap, ramah, sopan, dan bersahabat) dalam memberikian pelayanan terhadap pelanggan, yang berupa :

- Competence (Kompetensi). Setiap orang dalam perusahaan memiliki keterampilan dan pengetahuan yang berhubungan dengan kebutuhan konsumen.

- Courtesy (Kesopanan). Sikap sopan santun dan keramahtamahan yang dimiliki oleh para contact person.

- .Creibility. Sifat jujur dan dapat dipercaya yang mencakup : nama perusahaan, reputasi perusahaan, karakteristik pribadi serta interaksi dengan konsumen.

e. Emphaty. Tingkat kepedulian dan perhatian perusahaan terhadap konsumen secara individu, sehingga memberikan kesan tersendiri bagi masing-masing pelanggan.

\section{Minat}

Minat konsumen tumbuh karena suatu motif berdasarkan atributatribut sesuai dengan keinginan dan kebutuhannya dalam menggunakan suatu pelayanan jasa, berdasarkan hal tersebut maka analisa mengenai bagaimana proses minat dari dalam diri konsumen sangat penting dilakukan(Paul J dan Olson, Jerry C. (2000). Perilaku minat konsumen adalah hasil dari evaluasi terhadap merek atau jasa. Tahapan terakhir dari proses tersebut adalah pengambilan keputusan secara kompleks termasuk menggunakan merek atau jasa yang diinginkan, mengevaluasi merek atau jasa tersebut pada saat digunakan dan menyimpan informasi untuk

Minat konsumen menunjukkan sejauh mana komitmennya untuk melakukan tindakan pembelian. Kebutuhan dan keinginan konsumen akan barang dan jasa berkembang dari masa ke masa yang mempengaruhi perilakunya. Perilaku konsumen didefinisikan sebagai kegiatan yang secara langsung terlibat dalam mendapatkan dan mempergunakan barang- 
barang dan jasa termasuk didalamnya proses pengambilan keputusan tersebut (Engel, J.F., R.D. Blackweel and P.W. Miniard, (1995).,

Minat dapat didefinisikan sebagai suatu sikap berupa kemauan untuk menggunakan atau mencoba suatu yang ditawarkan oleh perusahaan (Schiffman, Leon G. dan Lestie L. Kanuk, 2004). Minat terhadap suatu produk atau jasa dapat dilihat berdasarkan ciri-ciri :

1. Kemauan untuk mencari informasi terhadap suatu produk atau jasa. Konsumen yang memiliki minat akan berusaha mencari informasi lebih detail tentang produk atau jasa dengan tujuan untuk mengetahui secara pasti bagaimana spesifikasi produk atau jasa yang digunakan, sebelum menggunakan produk atau jasa tersebut.

2. Kesediaan untuk membayar barang atau jasa. Konsumen yang memiliki minat terhadap suatu produk/jasa dapat dilihat dari pengorbanan yang dilakukan. Konsumen yang cenderung memiliki minat lebih terhadap suatu produk/jasa akan bersedia untuk membayar produk/jasa tersebut dengan tujuan konsumen yang berminat tersebut dapat menggunakan barang atau jasa tersebut.

3. Menceritakan hal yang positif. Konsumen yang memiliki minat terhadap suatu produk/jasa, maka secara otomatis konsumen tersebut akan mencitrakan hal yang positif terhadap konsumen lain.

4. Kecenderungan untuk merekomendasikan. Konsumen yang memiliki minat terhadap produk, akan menceritakan hal yang positif dan akan merekomendasikan kepada orang lain untuk menggunakan produk/jasa tersebut. .

\section{METODE PENELITIAN}

\section{Jenis Penelitian}

Jenis penelitian ini adalah penelitian deskriptif yang didasarkan atas survey terhadap objek penelitian. Penelitian deskriptif adalah penelitian yang menggambarkan suatu fenomena berkaitan dengan populasi penelitian atau estimasi proporsi populasi yang mempunyai karakteristik tertentu (Cooper and Schindler, 2003)

\section{Populasi dan Sampel}

Populasi dalam penelitian ini adalah seluruh siswa kelas 3 dari SMU Negeri maupun Swasta yang ada di Provinsi Sumatera Utara. Pemilihan sampel dilakukan secara purposive sampling, yaitu seleksi data yang didasarkan pada kriteria tertentu atau judgement sampling. Sampel 
penelitian dipilih 10(sepuluh) SMU yang dianggap repsentatif dan yang diteliti hanya siswa kelas 3(tiga) dengan perincian dipilih 30 siswa dari masing - masing SMU yang terpilih sebagai obyek penelitian, maka jumlah sampel sebanyak 300 responden.

\section{Definisi Operasional dan Pengukuran Variabel}

Untuk dapat memberikan penjelasan tentang permasalahan yang dihadapi dalam penelitian ini, maka definisi operasional variabel penelitian yaitu :

Tabel 1. Variabel dan Defenisi Operasional

\begin{tabular}{|c|c|c|c|}
\hline $\begin{array}{l}\mathbf{N} \\
\mathbf{0}\end{array}$ & Defenisi Variabel & Indikator & $\begin{array}{c}\text { Skala } \\
\text { Pengukuran }\end{array}$ \\
\hline 1. & $\begin{array}{l}\text { Minat mahasiswa (Y). Sejauh } \\
\text { mana responden menunjukkan } \\
\text { komitmennya untuk memilih } \\
\text { Perguruan Tinggi Swasta yang } \\
\text { ada di Provinsi Sumatera Utara }\end{array}$ & $\begin{array}{l}\text { 1. Kesediaan untuk membayar } \\
\text { produk atau jasa } \\
\text { 2. Kecenderungan } \\
\text { merekomendasikan } \\
\text { 3. } \text { Menceritakan hal yang positif }\end{array}$ & Ordinal \\
\hline 2. & $\begin{array}{l}\text { Pencitraan (X1). Merupakan } \\
\text { pandangan ataupun persepsi } \\
\text { atas Perguruan Tinggi Swasta } \\
\text { yang ada di Provinsi Sumatera } \\
\text { Utara }\end{array}$ & $\begin{array}{l}\text { 1. Memiliki staf-staf pengajar } \\
\text { profesional } \\
\text { 2. Memiliki kredibilitas tinggi } \\
\text { 3. Dijalankan manajemen yang } \\
\text { berpengalaman } \\
\text { 4. Reputasi yang baik daripada } \\
\text { pesaing } \\
\text { 5. Popularitas tinggi }\end{array}$ & Ordinal \\
\hline 3. & $\begin{array}{l}\text { Promosi (X2). Merupakan } \\
\text { bentuk informasi atau persuasi } \\
\text { satu arah yang di disampaikan } \\
\text { masing - masing Perguruan } \\
\text { Tinggi Swasta yang ada di } \\
\text { Provinsi Sumatera Utara }\end{array}$ & $\begin{array}{l}\text { 1. Kegiatan periklanan } \\
\text { 2. Promosi dengan memberikan } \\
\text { diskon atau potongan harga } \\
\text { 3. Promosi bertindak sebagai } \\
\text { sponsor suatu kegiatan } \\
\text { 4. Promosi dilakukan dengan } \\
\text { pemampangan di tempat umum } \\
\text { 5. Promosi dilakukan melalui media } \\
\text { internet }\end{array}$ & Ordinal \\
\hline 4. & $\begin{array}{l}\text { Kualitas pelayanan (X3) } \\
\text { Merupakan tingkat keunggulan } \\
\text { yang diberikan Perguruan } \\
\text { Tinggi Swasta yang ada di } \\
\text { Provinsi Sumatera Utara secara } \\
\text { konsisten untuk memenuhi } \\
\text { harapan konsumen }\end{array}$ & $\begin{array}{l}\text { 1. Tangibles (bukti Fisik) } \\
\text { 2. Reliability (Kehandalan) } \\
\text { 3. Responsiveness (Daya tanggap) } \\
\text { 4. Assurance (Jaminan) } \\
\text { 5. Emphaty (Empati). }\end{array}$ & Ordinal \\
\hline
\end{tabular}




\section{Model Analisis}

Metode analisis menggunakan regresi berganda untuk mengetahui pengaruh variabel bebas terhadap variabel terikat (Sugiono, 2002).

$$
Y=\beta 0+\beta 1 . X 1+\beta 2 . X 2+\beta 3 . X 3+e i \text {. }
$$

Keterangan : $\boldsymbol{Y}=$ Variabel terikat, $\boldsymbol{X 1}, \boldsymbol{X} \mathbf{2}$ dan $\boldsymbol{X} \mathbf{3}=$ Variabel bebas, $\boldsymbol{\beta} \mathbf{0}=$ Konstanta, $\boldsymbol{\beta} 1, \boldsymbol{\beta 2}, \boldsymbol{\beta 3}=$ Koefisien Regresi, $\boldsymbol{e} \boldsymbol{i}=$ Kesalahan dalam estimasi

Persamaan diatas diaplikasikan untuk melihat pengaruh variabel bebas (pengaruh pencitraan, promosi dan kualitas pelayanan terhadap minat mahasiswa memilih Perguruan Tinggi Swasta di Sumatera Utara dengan rumus :

$$
Y=\beta o+\beta 1 \times 1+\beta 2 . \times 2+\beta 3 . \times 3+e i
$$

Keterangan : $\boldsymbol{Y}=$ Variabel Minat Mahasiswa, $\boldsymbol{X} \mathbf{1}=$ Variabel Pencitraan, $\boldsymbol{X 2}=$ Variabel Promosi, $\boldsymbol{X} \mathbf{3}=$ Variabel Kualitas pelayanan, $\beta o=$ Koefisien konstanta, $\beta 1, \beta 2, \beta 3=$ Koefisien regresi, $\boldsymbol{e i}=$ Error

\section{Pengujian Asumsi Klasik}

Pengujian asumsi klasik dilakukan dengan melakukan uji normalitas, uji multikolonieritas dan uji heteroskedastisitas.

\section{Uji Normalitas Data}

Uji normalitas data bertujuan untuk menguji salah satu asumsi dasar analisis regresi berganda, yaitu variabel-variabel independent dan depenent harus didistribusikan normal atau mendekati normal, untuk menguji apakah data-data yang dikumpulkan berdistribusi normal atau tidak dapat dilakukan dengan metode grafik. Metode grafik yang handal untuk menguji normalitas data adalah dengan melihat normal probability plot, sehingga hampir semua aplikasi komputer statistic menyediakan fasilitas ini. Normal probability plot adalah membandingkan distribusi komulatif data yang sesungguhnya dengan distribusi komulatif dari distribusi normal (hypotheeical distribution). Proses uji normalitas data dilakukan dengan meperhatikan penyebaran data (titik) pada Norma P-Plot of Regression Standardized dari variabel terikat (Singgih Santoso, 2000) dimana :

1. Jika data menyebar di sekitar garis diagonal, maka model regresi memenuhi asumsi normalitas. 
2. Jika data menyebar jauh dari diagonal atau mengikuti garis diagonal, maka model regresi tidak memenuhi asumsi normalitas.

\section{Uji Multikolinieritas}

Uji multikolinearitas dilakukan untuk menguji apakah pada model regresi ditemukan adanya korelasi antar variabel independent, jika terjadi korelasi, maka dinamakan terdapat problem multikolinearitas. Model regresi yang baik seharusnya tidak terjadi korelasi diantara variabel independent. Uji multikolinearitas pada penelitian dilakukan dengan matriks korelasi. Pengujian ada tidaknya gejala multikolinearitas dilakukan dengan meperhatikan nilai matriks korelasi yang dihasilkan pada saat pengolahan data serta nilai VIF (Variance Inflation Factor) dan Tolerancenya, apabila nilai matriks korelasi tidak ada yang lebih besar dari 0,5 maka dapat dikatakan data yang akan dianalisis terlepas dari gejala multikolinearitas, kemudian apabila nilai VIF berada dibawah 10 dan nilai Tolerance mendekati 1, maka diambil kesimpulan bahwa model regresi tersebut tidak terdapat problem multikolinearitas (Singgih Santoso, 2000)

\section{Uji Heteroskedastisitas}

Uji heteroskedastisitas dilakukan untuk menguji apakah dalam sebuah model regresi terjadi ketidaksamaan varians dari residual dari satu pengamatan satu ke pengamatan yang lain, jika varians dari residu atau dari satu pengamatan ke pengamatan yang lain tetap, maka disebut homokedastisitas. Dan jika varians berbeda maka disebut heteroskedastisitas. Model regresi yang baik adalah tidak terjadi heteroskedastisitas (Singgih Santoso,2000). Salah satu cara untuk mendeteksi heteroskedastisitas adalah dengan melihat grafik scatter plot antara nilai prediksi variable terikat (2 PRED) dan nilai residualnya (5 RESID).

\section{Pengujian Hipotesis}

Untuk menguji hipotesis digunakan uji $\mathrm{F}$ dan $\mathrm{t}$.

- Uji F

1. $\mathrm{H}_{0}: \beta \mathrm{i}=0$, artinya tidak ada pengaruh yang signifikan variabel pencitraan, promosi dan kualitas pelayanan secara simultan terhadap minat mahasiswa memilih Perguruan Tinggi Swasta di Sumatera Utara. 
$\mathrm{H}_{1}: \beta \mathrm{i} \neq 0$, artinya ada pengaruh yang signifikan variabel pencitraan, promosi dan kualitas pelayanan secara simultan terhadap minat mahasiswa memilih Perguruan Tinggi Swasta di Sumatera Utara.

2. Tingkat Keyakinan $95 \%$ Level of significan $(\alpha)=5 \%$

3. Uji statistik F:

$$
F=\frac{R^{2} /[k-1]}{\left[1-R^{2}\right] /(n-k)}
$$

Keterangan : $\mathrm{k}=$ Jumlah variabel, $\mathrm{R}^{2}=$ koefisien determinan, $\mathrm{n}=$ Jumlah sampel

4. Kriteria pengujian: $\mathrm{H}_{0}$ diterima jika $\mathrm{F}$ hitung $\leq \mathrm{F}$ tabel, $\mathrm{H}_{1}$ diterima jika $\mathrm{F}$ hitung $>\mathrm{F}_{\text {tabel }}$

5. Kesimpulan : Dengan membandingkan langkah 3 dan 4 untuk menerima atau menolak hipotesis.

- Uji t

1. $\mathrm{H}_{0}: \beta \mathrm{i}=0$, artinya tidak ada pengaruh yang signifikan variabel pencitraan, promosi dan kualitas pelayanan secara parsial terhadap minat mahasiswa memilih Perguruan Tinggi Swasta di Sumatera Utara.

$\mathrm{H}_{1}: \beta \mathbf{i} \neq 0$, artinya ada pengaruh yang signifikan variabel pencitraan, promosi dan kualitas pelayanan secara parsial terhadap minat mahasiswa memilih Perguruan Tinggi Swasta di Sumatera Utara.

2. Tingkat Keyakinan $95 \%$ Level of significan $(\alpha)=5 \%$

3. Uji statistik $t$ :

$$
t=\frac{\beta s-\beta}{S . E[\beta s]}
$$

Keterangan: $\mathrm{t}=\mathrm{t}_{\text {hitung, }}, \beta_{\mathrm{S}}=$ koefisien regresi, $\mathrm{S} . \mathrm{E}[\beta \mathrm{i}]=$ Standar error koefisien regresi

4. Kriteria pengujian: $\mathrm{H}_{0}$ diterima jika $-\mathrm{t}_{\alpha / 2}: \mathrm{dk} \leq \mathrm{t}_{\text {hitung }} \leq \mathrm{t}_{\alpha / 2}: \mathrm{dk}$

$\mathrm{H}_{1}$ diterima jika $\mathrm{t}_{\text {hitung }}>\mathrm{t}_{\alpha / 2}$ : $\mathrm{dk}$ atau $\mathrm{t}_{\text {hitung }}<-\mathrm{t}_{\alpha / 2}: \mathrm{dk}$

5. Kesimpulan : Dengan membandingkan langkah 3 dan 4 untuk menerima atau menolak hipotesis. 


\section{DAFTAR PUSTAKA}

Eko Indrajit.2006. Manajemen Perguruan Tinggi Modern, Yogyakarta : Penerbit Andi.

Chrisdiawan Satriyo Nugroho, 2010, Analisis Pengaruh Pencitraan, Promosi dan Kualitas Pelayanan Terhadap Minat Kuliah di Diploma III Fakultas Ekonomi Universitas Diponegoro Semarang

Cooper, Donald R. and Pamela S.Schindler, 2003, Business Research Methods, Eighth Edition, McGraw-Hill, Inc. New York.

Dharmmesta, B. S. (1997), Manajemen Pemasaran Analisa Perilaku Konsumen. Edisi 1. Yogyakarta: BPFE.

David Loudon dan Albert J.Della Bitta.1993.Consumer Behaviour Concept and Application, Penerbit Mc Grow Hill Book. Co

Erna Ferrinadewi dan S. Pantja Djati. 2004. "Upaya Mencapai Loyalitas Konsumen Dalam Perspektif Sumber Daya Manusia" . Jurnal Manajemen \& Kewirausahaan, Vol. 6, No. 1, Maret 2004: 15 - 26

Engel, J.F., R.D. Blackweel and P.W. Miniard, (1995), Perilaku Konsumen, jilid 1. Edisi ke enam, terjemahan oleh Budiyanto, Binarupa Aksara, Jakarta.

Fandy Tjiptono. 1999. Strategi Pemasaran. Yogyakarta : Andi.

Lamb, Charles W; Hair, Joseph F., McDaniel, Carl. 2001. Pemasaran. Buku 1, Alih Bahasa: David Octarevia, Jakarta: Salemba Empat.

Kotler, Philip 2000. Manajemen Pemasaran di Indonesia: Analisis, Perencanaan, Implementasi dan Pengendalian. Buku 1, Alih Bahasa: Hermawan, Edisi Pertama, Jakarta: Salemba Empat.

Kotler, Philips dan Armstrong, Gary. 2004. Dasar-dasar Pemasaran, Jilid 1, Alih Bahasa : Alexander Sindoro, Edisi Kesembilan, Jakart: Indeks.

Nur Indriantoro dan Bambang Supomo. 2002. Metodologi Penelitian Bisnis Yogyakarta : Fakultas Ekonomi Universitas Gajahmada

Parasuraman, A., Valerie A. Zeithaml, dan Leonard L. Berry (1988), “A Multiple Item Scale for Measuring Consumer Perception on Future Research", Journal of Marketing, Vol. 49/1.

Peter, Paul J dan Olson, Jerry C. 2000. Costumer Behavior: Perilaku Konsumen dan Strategi Pemasaran. Alih Bahasa: Damos Sihombing. Jakarta: Erlangga.

Reinartz Werner, et al. 2004. "The Customer Relatinship management Process : It's measurement and Impact on Performance". Journal of Marketing Research . Vol. XLI, P 293-305. 
Santoso, Singgih. 2000. SPSS Statistik Parametrik, Jakarta : PT Elex Media Computindo.

Schiffman, Leon G. dan Lestie L. Kanuk, 2004. Consumer Behavior, Fifth Edition, Prentice Hall Inc, Ney Jersey

Sugiyono, 2002. Metode Penelitian, Cetakan Keenam, Bandung: Alfabeta.

Sutisna, 2001. Perilaku Konsumen dan Komunikasi Pemasaran, Edisi Pertama, Jakarta : Rosda. 